\title{
PEMBERDAYAAN PETANI LAHAN GAMBUT MELALUI PROSES PENJERNIHAN AIR GAMBUT
}

\section{EMPOWERMENT OF FARMERS ON PEATLAND THROUGH WATER TREATMENT PROCESS}

\author{
${ }^{1)}$ Tri Widiastuti, ${ }^{2}$ Siti Latifah \\ ${ }^{1,2)}$ Program Studi Kehutanan, Fakultas Kehutanan Universitas Tanjungpura \\ Jl. Daya Nasional Pontianak 78124 \\ email :wiknok@yahoo.com
}

\begin{abstract}
ABSTRAK
Masyarakat di kawasan gambut umumnya mengandalkan air hujan untuk kebutuhan air bersih seharihari, akan tetapi ketersediaan air hujan menjadi terbatas pada musim kemarau, itu berarti tidak ada pilihan lain selain memanfaatkan air gambut yang mengalir di parit dilingkungan tempat tinggal mereka. Program KKN PPM bertujuan untuk memberdayakan petani melakukan penjernihan air gambut melalui program alih teknologi dan pendampingan petani. Penjernihan air gambut menggunakan bahan - bahan alami yang mudah didapatkan dilingkungan sekitar mereka, yaitu menggunakan kapur sirih, PAC dan Tawas sebagai koagulan penjernihan air dan juga menggunakan batu kerikil, pasir, arang dan ijuk sebagai filter pada proses penyaringan air. Sasaran utama adalahkelompok tani pengguna air gambut anggota Gapoktan Sumber Bersama yang berada di kampung Kembang Wonosari, dusun Karya 1, desa Kuala Dua. Kegiatan KKN PPM diselenggarakan selama Ibulan diikuti oleh 30 mahasiswa, Metode yang diterapkan adalah membuat plot percontohan,penyuluhan, bersama Poktan membuat sumur resapan, instalasi dan demo penjernihan air gambut.Pada 6 lokasi yang berbeda telah berhasil didirikan 6 buah instalasi pengolahan air gambut dan 6 sumur resapan, Melalui kegiatan KKN-PPM ini para petani telah dapat melakukan penjernihan air secara mandiri dan dapat mengatasi kesulitan air bersih pada musim kemarau.
\end{abstract}

Kata kunci : air gambut, penjernihan, sumur

\begin{abstract}
Communities in peatlands usually rely on rainwater for their daily clean water needs. However, the availability of rainwater is limited during dry season, which means there is no other choice other than to take advantage of peatland surface water that flows through canals or ditches in their neighborhoods. The KKN PPM program aims to empower the communities to purify peat water through technology transfer and farmer involvement programs. Purification of peatland water was done using natural materials that can easily be found in their surroundings, such as using lime, PAC and Tawas as coagulant of water purification and also utilize pebbles, sand, charcoal and 'ijuk' fibers as a filter on the water filtration process. The community group target for peat water purification was the member of Gapoktan Sumber Bersama located in Kembang Wonosari area of Karya 1 sub village in Kuala Dua village of Kubu Raya District. KKN PPM activities were held for one month supported by 30 students involvement. The method applied during the program was to make pilot plot, counseling, and together with farmers'group to make absorption well, installation and demo of peat water purification. Within 6 different sub-sub village, it had been successfully established six peat water treatment plants and 6 absorbing wells. Through the KKN-PPM activities, farmers have been able to do water purification independently and could overcome the difficulty of clean water in the area especially in dry season.
\end{abstract}

Keywords: peatland water, water purification, wells

Submited : 28 April 2017 Revision:6 Juli 2017 Accepted:12 September 2017 


\section{PENDAHULUAN}

Lahan gambut merupakan salah satu sumberdaya lahan yang mempunyai fungsi hidrologis, sangat potensial menyimpan air berupa air gambut. Air gambut adalah air permukaan yang mempunyai ciri-ciri berwarna merah kecoklatan, $\mathrm{pH}$ rendah, kandungan zat organik yang tinggi, kekeruhan dan kandungan partikel tersuspensi dan kandungan kation yang rendah, warna coklat kemerahan pada air gambut merupakan akibat dari tingginya kandungan zat organik terlarut terutama dalam bentuk asam humus dan turunannya (Kusnaedi,2006). Asam humus tersebut berasal dari dekomposisi bahan organik seperti daun, pohon atau kayu dengan berbagai tingkat dekomposisi. Secara umum, air dengan nilai $\mathrm{pH}$ rendah akan asam, mengandung padatan rendah dan korosif, kondisi ini dapat menyebabkan air berasa asam atau rasa logam, noda pada baju, dan noda pada tempat cucian di dapur dan pembuangan, kurang baik untuk dikonsumsi karena beresiko menganggu kesehatan. Berdasarkan hasil penelitian Suhendar dkk (2012) air gambut di di dusun Pulo Gombut Desa Suka Rame Baru Kecamatan Kuala Hulu Kabupaten Labuhan Batu Utara kualitas fisik parameter warna dan kekeruhan tidak memenuhi standar kelas I. Kualitas kimia parameter $\mathrm{pH}$ air gambut sangat rendah $(4,5$ - 4,8) dan kandungan $\mathrm{Fe}(0,9 \mathrm{mg} / \mathrm{L})$, Mn $(0,17 \mathrm{mg} / \mathrm{L})$ dan BOD $(15,73-16,27$ $\mathrm{mg} / \mathrm{L})$ melebihi standar yang ditetapkan. Kualitas mikrobiologis, parameter total coliform memenuhi standar kelas I. Meskipun demikian keluhan kesehatan masih banyak dirasakan masyarakat. yang paling banyak dialami masyarakat akibat penggunaan air gambut adalah gatal-gatal $(72,4 \%)$, diare $(19,0 \%)$ dan kulit bersisik $(8,6 \%)$.

Desa Kuala Dua merupakan salah satu desa di wilayah Kecamatan Sei Raya Kabupaten Kubu Raya Kalimantan Barat yang memiliki lahan gambut cukup luas. Pada kawasan gambut, kebutuhan air bersih masyarakat belum dapat diakomodasi oleh PDAM, pipa ledeng belum menjangkau wilayah tinggal mereka. Umumnya masyarakat mengandalkan air hujan untuk konsumsi sehari-hari dengan cara menampungnya pada saat terjadi hujan ke dalam bak tampungan, akan tetapi ketersediaan air hujan menjadi terbatas pada musim kemarau, apalagi pada musim kemarau tersebut banyak masyarakat yang melakukan pembakaran untuk membersihkan atau membuka lahannya, sehingga asap dan debu hasil pembakaran mencemari udara, apabila terjadi hujan airnya tidak dapat ditampung karena kotor tercemar debu sisa pembakaran lahan. Kondisi ini menyebabkan masyarakat tidak mempunyai pilihan lain untuk memanfaatkan air gambut yang mengalir di parit-parit atau saluran drainase dilingkungan tempat tinggal mereka.

Telah banyak metode penjernihan air yang dikembangkan, salah satunya diterapkan dalam program KKN PPM ini dengan melalui alih teknologi dan pendampingan petani untuk melakukan penjernihan air gambut, menggunakan bahan - bahan alami yang mudah didapatkan dilingkungan sekitar mereka, yaitu kapur sirih, PAC dan Tawas sebagai koagulan penjernihan air dan juga menggunakan batu kerikil, arang, ijuk, pasir dan spon sebagai filter pada proses penyaringan air. Penggunaan kapur sebagai bahan penjernih dan penaikan keasaman air gambut ini sesuai dengan penelitian yang dilakukan Hazmani , dkk (2017) Untuk air yang bersifat asam, yang paling murah dan mudah adalah pemberian kapur tohor $(\mathrm{CaO})$ atau batu gamping (CaCO3). Berdasarkan hasil penelitian pada variasi kelarutan kapur dengan konsentrasi yang berbeda menunjukkan hasil relatif sama yaitu konsentrasi $1,0 \% \mathrm{pH}$ air menjadi 12,49 ; konsentrasi $0,5 \% \mathrm{pH}$ air menjadi 12,47 dan konsentrasi $0,1 \% \mathrm{pH}$ air menjadi 12,18. Pada uji lanjutan larutan kapur konsentrasi $0,5 \%$ sebesar $9 \mathrm{~mL}$ pada 500 $\mathrm{mL}$ sampel air gambut mampu menaikkan 
Tri Widiastuti, Siti Latifah

Pemberdayaan Petani Lahan Gambut Melalui Proses Penjernihan Air Gambut

pH 4,06 menjadi 7,77. Hasil uji jartest menunjukkan injeksi larutan kapur $5 \mathrm{~mL}$ dan tawas $2 \mathrm{~mL}$ mampu menaikkan $\mathrm{pH}$ air baku 4,02 menjadi 7,24 memenuhi persyaratan air minum $\mathrm{pH}$ 6,5-8,5. Dosis optimum proses netralisasi $\mathrm{pH} \pm 4$ pada air gambut adalah konsentrasi larutan kapur $0,5 \%$ sebesar $5 \mathrm{~mL}(50 \mathrm{mg} / \mathrm{L})$ dan konsentrasi larutan tawas $0,5 \%$ sebesar 2 $\mathrm{mL}(20 \mathrm{mg} / \mathrm{L})$.

Pelaksanaan KKN melibatkan peran aktif mahasiswa,sasaran utamanya adalah kelompok tani yang berdomisili dan atau memiliki lahan garapan dalam wilayah dusun tersebut. Saat ini kelompok tani di desa Kuala Dua yang tergabung dalam organisasi Gabungan Kelompok Tani (Gapoktan) Sumber Bersama berjumlah 17 kelompok tani, total anggota 461 orang dengan luas wilayah garapan keseluruhan $\pm 600 \mathrm{Ha}$, kegiatan kelompok tani lebih banyak berkaitan dengan peningkatan kualitas dan kuantitas produksi lahan pertanian.

Tujuan utama kegiatan KKN PPM ini adalah membuka wawasan dan memberikan ketrampilan bagi para petani untuk dapat melakukan penjernihan air gambut secara mandiri.

\section{METODE}

1. Persiapan dan Pembekalan

Kegiatan persiapan untuk KKN PPM ini adalah melakukan koordinasi bersama ketua Gapoktan Sumber Bersama untuk menentukan jadwal pelaksanaan dan menentukan kelompok tani sasaran sosialisasi. Sementara itu dilakukan pula perekrutan 30 mahasiswa sebagai peserta KKN PPM, sebelum diterjunkan kelapangan dilakukan pembekalan mahasiswa dengan materi pembekalan meliputi manajemen kelompok dan sosiologi pedesaan, tanah gambut dan air gambut, pembuatan instalasi penjernihan, teknik penjernihan air gambut serta pembuatan sumur resapan. Selain itu juga dilakukan persiapan alat dan bahan yang akan digunakan dalam melaksanakan program KKN PPM ini, yaitu alat-alat pertukangan seperti : gergaji kayu, gergaji besi, palu, penggali, ember, gayung, meteran, pahat, bor listrik, mesin air. Adapun bahan-bahan yang digunakan untuk pembuatan instalasi dan sumur adalah: bak air 200lt, kayu belian, papan, pipa 6", dop pipa 6", pipa 1", socket drat luar, socket drat dalam, elbo 1", tee 1", stop kran 1", Keran 1", lem pipa, amplas, paku, kawat kasa, kayu lap, semen dan gorong-gorong. Bahan filter dan koagulan adalah : pasir, batu kerikil, arang kayu, ijuk, spon, kapur sirih, PAC dan tawas.

\section{Pelaksanaan}

Kegiatan utama KKN PPM ini adalah melaksanakan tematiknya yaitu membangun instalasi pengolahan air gambut dan membuat sumur resapan. Sasaran program ini adalah kelompok tani (Poktan) pengguna air gambut di Kampung Wonosari, dusun Karya Satu, desa Kuala Dua, Poktan yang didampingi adalah Poktan Wonosari 1, Poktan Wonosari 3 dan Poktan Wonosari 4. Pemasangan instalasi pengolahan air gambut dilaksanakan pada 6 lokasi, dan masingmasing lokasi didampingi 5 orang mahasiswa dengan lama kegiatan sekitar 1 bulan. Adapun metode yang diterapkan untuk pemberdayaan kelompok sasaran adalah sebagai berikut :

a. Pada satu lokasi mahasiswa bersama pemilik lahan membangun instalasi pengolahan air gambut dan membuat sumur resapan sebagai plot percontohan.

b. Selanjutnya 5 kelompok mahasiswa lainnya bersama-sama dengan pemilik lahan dan masyarakat sekitarnya membangun 5 instalasi pengolahan air gambut dan sumur resapan pada masing-masing lokasi.

c. Melakukan sosialisasi tentang instalasi pengolahan air gambut dan teknik penjernihan air gambut.

d. Demonstrasi teknik penjernihan air gambut. 
Tri Widiastuti, Siti Latifah

Pemberdayaan Petani Lahan Gambut Melalui Proses Penjernihan Air Gambut

e. Melakukan monitoring dan evaluasi.

\section{HASIL DAN PEMBAHASAN}

Pelaksanaan kegiatan KKN PPM di Kampung Kembang Wonosari, Dusun Karya I, Desa Kuala Dua telah berhasil membangun 6 perangkat instalasi penjenihan air gambut dan 6 buah sumur resapan. Penentuan titik lokasi pembangunan instalasi dan pembuatan sumur resapan ditetapkan berdasarkan kesepakatan Ketua Gapoktan dengan para Ketua Poktan di kawasan Kampung Kembang Wonosari. Adapun lokasi penempatan instalasi dan sumur tersebut adalah : 2 unit berada di wilayah Poktan Wonosari 1 yaitu di Gg. Mekar dan Gg. Rukun, 2 unit berada di wilayah Poktan Wonosari 2 yaitu di Gg. Samudra Depan dan Gg. Samudra Dalam dan 2 unit lagi di wilayah Poktan Wonosari 4, yaitu dirumah Ketua Gapoktan dan Mesjid Amanatul Hasanah. Setiap unit instalasi mempunyai bak tampungan untuk 200 liter air, jika proses penjernihan dilakukan rutin maka kapasitas olah air bisa mencapai $600 \mathrm{sd}$, 800 liter per hari.

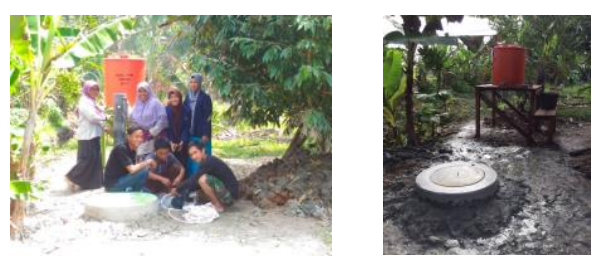

Gambar Instalasi dan Sumur Resapan

Sosialisasi kegiatan tematik KKN PPM ini mendapatkan respon sangat baik, keingintahuan yang besar dari masyarakat Poktan terlihat dari banyaknya pertanyaan yang diajukan, transfer pengetahuan dan teknologi diawali dengan penyuluhan tentang cara pembuatan instalasi penjernihan air, operasional penggunaan instalasi dan teknik menjernihkan air gambut serta perawatan instalasi penjernih. Selain itu disampaikan pula tentang pentingnya membuat sumur resapan karena selama ini masyarakat menggunakan air gambut dari sungai/parit yang mengalir di sekitar rumah mereka, dengan kondisi kemungkinan tercemar oleh sisa buangan kegiatan penduduk seperti mandi, cuci dan juga kotoran hewan ternak yang bebas berkeliaran di sekitar area parit. Kondisi sumber air parit/ sungai yang demikian dapat menyebabkan beberapa keluhan kesehatan seperti yang dikemukakan oleh Suhendra, dkk (2012) bahwa penggunaan air sungai untuk keperluan MCK dapat menyebabkan keluhan kesehatan paling dominan adalah gatal-gatal, diikuti keluhan diare dan kulit bersisik. Sumur resapan dibuat denagn diameter sekitar $80 \mathrm{~cm}$ dan kedalaman sekitar $5 \mathrm{~m}$, sumur ini berfungsi untuk mendapatkan sumber air yang lebih bersih dan tertutup, guna menekan gangguan kesehatan yang mungkin timbul di masyarakat.

Masyarakat sangat antusias mengikuti kegiatan sosialisasi tentang proses penjernihan air gambut karena bahan - bahan filter dan koagulan yang digunakan mudah didapat dilingkungan sekitarnya. Kapur sirih berfungsi sebagai koagulan yang dapat meningkatkan $\mathrm{pH}$ air, pemberian PAC dan tawas yang bersifat sebagai pengikat zat-zat tersuspensi dan terlarut sehingga menyebabkan air menjadi jernih. Seperti yang dikemukakan oleh Suherman dan Sumawijaya (2013) bahwa ada prosedur yang sederhana untuk menghilangkan warna dan zat organik dalam air gambut yaitu setiap 1000 (seribu) $\mathrm{ml}$ air gambut diperlukan penambahan 0,10 gram kaporit 0,05 gram kapur tohor 0,30 gram tanah lempung dan 0,40 gram tawas. Setiap penambahan zat, dilakukan pengadukan secara manual dengan batang pengaduk selama 30 detik. Hanya dalam waktu 5 menit, terbentuk larutan yang bening dan endapan berwarna coklat. Prosedur ini juga dilakukan di lokasi KKNPPM dengan air baku adalah air gambut yang berasal dari parit/sungai sebanyak 100 liter, dosis bahan penjernih adalah 2 sdm kapur sirih, 1,5 sdm tawas dan 1 sdm PAC dengan pengadukan selama 5 menit. 
Tri Widiastuti, Siti Latifah

Pemberdayaan Petani Lahan Gambut Melalui Proses Penjernihan Air Gambut

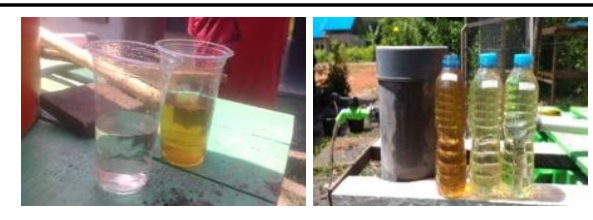

Gambar Hasil Penjernihan Air Gambut

Hasilnya menunjukan perbedaan yang cukup signifikan antara air gambut sebelum proses penjernihan dan air parit yang telah melalui proses penjernihan. Proses penjernihan juga dilakukan untuk air dari sumur resapan dengan komposisi dosis koagulannya hanya setengah dari koagulan yang digunakan dalam proses penjernihan air gambut dai parit/sungai, karena kondisi air yang bersumber dari sumur resapan lebih jernih dibandingkan dengan air gambut yang berasal dari parit/sungai.

\section{SIMPULAN}

Pelaksanaan program KKN PPM Pemberdayaan Petani Lahan Gambut Melalui Proses Penjernihan Air Gambut telah menghasilkan 6 unit instalasi penjernihan air dan 6 sumur resapan yang telah dibangun di 6 lokasi dalam wilayah Kampung Kembang Wonosari, dusun Karya I, desa Kuala Dua, kabupaten Kubu Raya. Kapasitas bak penjernih setiap unit adalah 200 liter dengan kemampuan menjernihkan air gambut 600 sd. 800 liter/hari. Kegiatan ini telah meningkatkan wawasan dan ketrampilan masyarakat tani untuk melakukan penjernihan air gambut secara mandiri guna memenuhi kebutuhan air bersih terutama pada musim kemarau.

\section{DAFTAR PUSTAKA}

Hamzani, S, Raharja, M, Ali, Z.As. 2017. Proses Nitralisasi $\mathrm{pH}$ pada Air Gambut di Desa Sawahan Kecamatan Cerbon Kabupaten Barito Kuala. Jurnal Kesehatan Lingkungan Vol. 14 No. 2, Juli 2017
Kusnaedi, 2006, Mengolah Air Gambut dan Air Kotor Untuk Air Minum, Bogor: Penebar Swadaya,

Suhendar, D.P, Marsaulina, I, Nuraini, D.S. 2012. Analisa Kualitas Air Gambut dan Keluhan Kesehatan Pada Masyarakat Di Desa Suka Rame Baru Kec. Kuala Hulu Kab. Labuhan Batu Utara. Medan : Dept. Kesehatan Lingkungan Fakultas Kesehatan Masyarakat Universitas Sumatera Utara

Suherman, D, Sumawijaya, Ny, 2013, Menghilangkan Warna dan Zat Organik air gambut dengan Metode Koogulasi-Flokulasi Suasana Basa. Jurnal: Riset Geologi dan Pertambangan vol 3 no 12 